\title{
ENUMERATION AS A MEANS OF FINANCIAL MARKETS DATA REPRESENTATION
}

\author{
Maryna Antonova \\ Taras Shevchenko National University of Kyiv, Kyiv, Ukraine \\ antonovakyiv@gmail.com
}

\begin{abstract}
Cognitive linguistics has developed into one of the most attractive and influential frameworks within linguistics at large. And it draws the linguists' attention to the study of aspects of language within cognitive paradigm as reflections of conceptual organization and categorization principles, as well as the ways of presenting knowledge about the world. This paper focuses on the cognitive analysis of enumeration as an instrument for organizing and conveying domainspecific information. The aim of the analysis is to establish the role of enumeration as a way of arriving at true knowledge of the world. The tasks of the research consist in the description of enumeration as a means of knowledge representation, as well as the study of the peculiarities of enumeration as a means of representation of financial markets information. The novelty of the analysis is defined by the study of enumeration as a means of representation of financial markets information. The theoretical value of the analysis is reasoned with the study of enumeration as a way of organizing knowledge that reflects collective experience of the community within a specific environment. The results of the study of enumeration in economic discourse show that it serves to structure and represent domain-specific knowledge.
\end{abstract} information.

Keywords: enumeration; cognitive linguistics; economic discourse; knowledge representation; domain-specific

Introduction. From a linguistic point of view, enumeration was considered within purely grammatical issue of homogeneous parts of speech until it was proved to be a stylistic device, the main structure variant of which is a construction of homogeneous parts of speech (Vetvinskaja, 1970, p. 1). According to I. Galperin "Enumeration is a stylistic device by which separate things, objects, phenomena, properties, actions are named one by one so that they produce a chain, the links of which, being syntactically in the same position (homogeneous parts of speech), are forced to display some kind of semantic homogeneity, remote though it may seem" (Galperin, 1974, p. 216).

The analysis of stylistic functions of enumeration was of primary importance within stylistic approach. Enumeration was studied by T. Vetvinskaja and V. Levashova as a means of a dynamic description, the one that develops subjective meaning, as well as the means that creates humorous expressive meanings in a text (Vetvinskaja, 1970; Levashova, 1977).

The effect of enumeration and its impact on the overall perceiving of the language of fictional prose was analysed on the material of Bridget Jones: The Edge of Reason written by Helen Fielding. In this study, enumeration was viewed by G. Siantova as a stylistic syntactical device. Enumeration was proved to be an inseparable part of the language of the selected literary piece which contributed to the success of the book. The frequent occurrence of enumeration was considered to bring humour and relaxed atmosphere to the whole reading (Siantova, 2013, p. 1-10).

Within the framework of the contemporary linguistic paradigm the structures of language are studied within cognitive perspective. Cognitive linguistic study of discourse has become stronger in recent past. On the one hand, cognitive linguistics focuses on language as an instrument for organizing, processing and conveying information, on the other, language users communicate through discourse rather than through isolated sentences (Sanders \& Spooren, 2007, p. 916).

Cognitive linguistic analysis is applied to different types of discourse. Thus, the architectonics of the subordinate concepts "marketing" and "company" in the contemporary business discourse was considered by L. Naumenko. As a result, the notional sense, schematic components, as well as the model of the concepts inner structure were developed (Naumenko, 2015a, 2015b). The poetic discourse was analysed by Ya. Gryshchenko. Consequently, the discursiveness features of the English ode of the XVIIth-XIXth centuries were distinguished (Gryshchenko, 2013). The historical developments in the forms and functions of reported discourse in news narratives were examined by K. Krieken \& J. Sanders. The cognitive linguistic model to a corpus of news narratives was applied (Krieken \& Sanders, 2016). Social and political discourse types were studied by C. Hart. As a consequence, the ideological functions of special construals in social and political discourse from a cognitive linguistic perspective were investigated (Hart, 2015). 
The use of cognitive approach to the analysis of enumeration in economic discourse allows establishing its nature as an instrument for organizing, processing and conveying information. Thus, the aim of the analysis is to establish the role of enumeration in representing domain-specific information. The tasks of the research consist in the study of enumeration as a means of financial markets data representation. The novelty of the analysis is defined by the study of enumeration as a means of representation of financial markets information. The theoretical value of the analysis is reasoned with the study of enumeration as a means of organizing knowledge that reflects collective experience of the community within a specific environment.

Knowledge representation. According to D. Geeraerts \& H. Cuyckens "Cognitive linguistics is the study of language in its cognitive function, where cognitive refers to the crucial role of intermediate informational structures in our encounters with the world... Cognitive linguistics is focusing on natural language as a means for organizing, processing, and conveying information. Language, then, is seen as a repository of world knowledge, a structured collection of meaningful categories that help us deal with new experiences and store information about old ones" (Geeraerts \& Cuyckens, 2007, p. 5).

Knowledge explore different areas and aspects of its existence and functioning. Knowledge representation is the area of methodological and systematic research that examines pragmatic characteristics of scientific knowledge, that is, the dependence of knowledge on the needs to which it is attracted (Sharov, Lubko \& Osadchyi, 2015, p. 109).

Knowledge representation can be understood in terms of five roles that it plays: as a surrogate or a substitute for the things of the world; a set of ontological commitments to think about the world; a theory of intelligent reasoning; a medium for pragmatical computation and finally, a language as a medium of human expression (Davis, Shrobe \& Szolovits, 1993, p. 17).

Due to the large flows of information in today's rapidly changing world, the problem of rapid analysis, processing and absorbing of knowledge is of critical importance. Thus, there is a crucial need for knowledge structuring, as well as the knowledge representation. Enumeration is considered to be one of the structures for representing knowledge.

According to S. Dubois \& D. Sankoff "Enumeration is a cumulative discourse process made of at least 2 different components that belong to the same or equivalent morphological and functional classes, that expresses a homogeneous whole, i.e., a cognitive schema or referential scene of which the enumerated elements form a part" (Dubois \& Sankoff, 1997, p. 160).

Enumeration from the cognitive linguistic perspective is considered to be of homogeneous and heterogeneous nature. While only heterogeneous enumerations were studied by stylistics (Galperin, 1974, p. 216), both homogeneous and heterogeneous enumerations are of interest for cognitive linguistics (Antonova, 2013, p. 98).

Structure of enumerative sequence. The analysis of the structure of enumeration showed that the degree of isolation of the elements of enumeration can be different. Therefore, elements can be separated not only by commas, but by dots, and even by paragraphs (Levinskaja, 1988).

The study of enumeration by M. Vergez-Couret, M. Bras, L. Prevot, L. Vieu \& C. Atallah discloses new insights into the contribution of enumerative structures involving the prepositional phrase pour deux raisons (for two reasons) as textual information to discourse structures and content. The prepositional phrase pour deux raisons is treated as a new type of discourse marker which discursive role within enumerative structures is to signal the content-level relation "explanation" (Vergez-Couret, Bras, Prevot, Vieu \& Atallah, 2011).

The structure of enumerative sequence in economic discourse is represented by linear and hierarchical constituents. The linear structure may consist of extended and unextended components of enumeration. In some cases more than one linear enumeration can be used in one sentence. In case of a hierarchical structure one of the elements of the main enumerative sequence is subdivided into a subordinate enumerative block (Antonova, 2012).

Enumeration as a means of representation of financial markets information. In this study, we have focused on the language of financial markets where enumeration is of frequent occurrence. The analysis showed that on the structural level the degree of isolation of the elements of enumeration can be different. The cases when the elements of enumeration are separated by commas are mainly the clauses 
of compound and complex sentences, whereas there are frequent enumerative patterns consisting of complete sentences which are separated by dots and even by paragraphs. Let's consider examples.

1. Commodities shares rallied as oil climbed above $\$ 36$ a barrel and iron ore prices surged, buoyed by U.S. growth signs and Chinese government plans to boost spending (O'Brien, 2016).

The relationship between commodity shares and commodity prices are represented by the homogeneous enumeration. It shows how the price of oil and iron ore affects the commodities share prices. The enumeration has a three-element structure, the elements of which are clauses of a complex sentence.

2. Measures of energy and raw-materials stocks on MSCI's Asia Pacific Index advanced more than 1 percent as BHP Billiton Ltd. climbed to a three-month high. The Bloomberg Commodity Index rose for a sixth day, the longest winning streak in two years, and iron ore jumped as much as 19 percent in Singapore. Crude advanced to a two-month high in New York, after surging by about 10 percent in each of the last two weeks. Australia's currency and copper retreated as a technical indicator signaled recent rallies were excessive. Japanese equities declined with U.S. index futures (O'Brien, 2016).

In this example, enumeration is used to describe the financial situation on the global markets. It provides information on the stock indices, the value of the currencies, commodity and share price movements in the world. Structurally the enumeration consists of independent and dependent clauses and complete sentences joined in one paragraph. The first two elements of the enumeration are connected by a subordinating conjunction "as" which shows the correlation between MSCI's Asia Pacific Index and BHP Billiton Ltd. The next elements of the enumeration provide information on the positive trend of Bloomberg Commodity Index, iron ore and crude prices, while the final elements of the enumeration show the decline of Australia's currency and copper, as well as of Japanese equities.

3. The Stoxx Europe 600 Index was little changed as of 8:15 a.m. London time, while the MSCI Asia Pacific Index retreated 0.2 percent. Benchmarks in Malaysia, South Korea and Thailand climbed to their highs for the year and Japan's Topix declined 1 percent, after surging 15 percent over the last three weeks.

Australia's S\&P/ASX 200 Index gained 1 percent, climbing for the sixth day in a row. Fortescue Metals Group Ltd., the world's fourth-largest iron-ore exporter, soared 24 percent. BHP Billiton, the biggest miner, jumped 5 percent after surging 13 percent last week.

Standard \& Poor's 500 Index futures fell 0.1 percent, after the gauge advanced 2.7 percent last week. (O’Brien, 2016)

This is an example of an enumeration, the elements of which are separated by paragraphs. It illustrates the highest degree of their isolation. The enumeration allows to compare the performance of the global stock market indices and securities. The first sentence of the first paragraph consists of two elements of the enumeration which are contrasted to each other by means of the conjunction "while". The second sentence has a hierarchical structure, as the first element of the enumeration is subdivided into three elements (Malaysia, South Korea, Thailand), which form a subordinate enumerative block. The second paragraph consists of the three complete sentences representing three elements of the enumeration which show a positive trend of the Australia indices and securities. The third paragraph consists of the final element of the enumeration which provides information on the American stock market index.

4. The ringgit gained as much as 1.1 percent to 4.0765 per dollar, the strongest level since August. The increase in crude prices is brightening prospects for Malaysia, Asia's only major net oil exporter. The rupiah strengthened for a 13th day, its best winning streak since 2010.

Australia's dollar fell 0.5 percent, after a 4.4 percent weekly surge that marked its best performance since 2011. The currency's 14-day relative strength index was 70 at the end of last week, a threshold that indicates to some traders a reversal of direction is likely.

The Bloomberg Dollar Spot Index, a gauge of the currency against 10 major peers, rose for the first time in six days. Odds of the Federal Reserve raising interest rates by December ticked up after the payrolls data, with the probability at 68 percent, up from 53 percent a week ago and 49 percent a month ago, according to Fed funds futures tracked by Bloomberg. (O'Brien, 2016)

As in the previous example, the elements of the enumeration are also separated by paragraphs. The enumeration provides information on major world currency indices and values. The first 
paragraph consists of the complete sentences representing two elements of the enumeration which give data on Malaysian ringgit exchange rates and Indonesian rupiah value. The second paragraph introduces the third element of the enumeration which provides information on Australia's dollar. The third paragraph contains two elements of the enumeration consisting of the complete sentences. The second sentence has a hierarchical structure, as the element of the enumeration is subdivided into three elements (with the probability at 68 percent, up from 53 percent a week ago and 49 percent a month ago), which form a subordinate enumerative block.

5. Australian bonds led declines among sovereign debt, with yields on notes due in a decade climbing three basis points to 2.58 percent. The rate on similar-maturity U.S. Treasuries was little changed at 1.88 percent, after adding four basis points on Friday. (O'Brien, 2016)

Enumeration, in this case, provides information on Australian and United States Treasury securities. The enumeration has a two-element structure, the elements of which are complete sentences combined in one paragraph.

6. If the start of the year has been desperate for the world's stockmarkets, it has been downright disastrous for shares in banks. Financial stocks are down by 19\% in America. The declines have been even steeper elsewhere. Japanese banks' shares have plunged by $36 \%$ since January 1st; Italian banks' by $31 \%$ and Greek banks' by a horrifying 60\%. The fall in the overall European banking index of 24\% has brought it close to the lows it plumbed in the summer of 2012, when the euro zone seemed on the verge of disintegration until Mario Draghi, the president of the European Central Bank (ECB), promised to do "whatever it takes" to save it. (Falling bank shares, 2016)

The enumeration, in this example, is used to describe the unfavourable conditions for shares in banks. On the structural level, the enumeration consists of independent clauses and complete sentences combined in one paragraph. The first element of the enumeration provides information on the decline of U.S. financial stock prices. The second sentence introduces the three elements of the enumeration represented by clauses, the two of which are elliptical ones. The elements of the enumeration are used to describe a substantial drop in Japanese, Italian and Greek banks' shares. And the final element of the enumeration gives information on the fall of the overall European banking index.

7. Just when it looked like calm had been restored to China's stockmarket, share prices nosedived in the last hour of trading on July 30th. Stocks listed on the ChiNext, an exchange for start-ups, fell 4.9\%, while the CSI300, an index of bigger companies, slid 2.9\%. It was the latest stomach-churning session in a wild few months. Since soaring to their peak in early June, Chinese stocks have dropped by nearly a third. Authorities have resorted to heavy-handed measures to prop up swooning share prices, from pressuring banks to buy stocks to blocking big investors from selling theirs. The wisdom of such intervention is highly dubious, but many analysts and investors had at least expected it would be effective. Why is China finding it so hard to save its stockmarket? (China's botched stockmarket rescue (CBSR), 2015)

The enumeration here describes the financial situation on the China's stock market. It provides information on the decline of the stock market indices and share prices. Structurally the enumeration consists of independent and dependent clauses and complete sentence joined in one paragraph. The second and the third elements of the enumeration are connected by a subordinating conjunction "while" which allows to compare the correlation between stocks listed on the ChiNext, an exchange for start-ups and the CSI300, an index of bigger companies.

8. The short answer is that, for all the government's involvement, China's stockmarket is still a market, and there are now more sellers than buyers. Even with the steep fall since early June, Chinese shares are up some $70 \%$ in the past year. Small-cap stocks, the focus of so much of the trading, remain too expensive. The price-to-earnings ratio of stocks listed on the ChiNext is 95, about twice the typical value for high-growth companies in more mature markets. Had China's stockmarket been allowed to crash, shares would have eventually found a floor. Instead, regulators have tried to erect a floor, and investors are not sure whether it really is the low point or just another artificial bottom susceptible to collapse. (CBSR, 2015)

Enumeration, in this case, provides information on the recovery of Chinese shares and stocks in comparison to their previous year values. The enumeration has a three-element structure consisting of complete sentences combined in one paragraph. 
Conclusions. In general, the analysis of enumeration in economic discourse shows that it serves to structure and represent domain-specific information. The study of enumeration as a means of financial data representation revealed that it provides information on the stock indices and securities, the value of the currencies, commodity and share price movements in the world. Moreover, on the structural level, the analysis indicates that in the language of financial markets enumeration has a different degree of isolation of its elements, which are separated not only by commas, but by dots, and even by paragraphs.

Substantial studies of enumeration from the cognitive perspective in different types of discourse are considered as prospects for further research.

\section{References:}

Antonova, M.Yu. (2013). Enumeration in Short Stories of W.S. Maugham: Cognitive Approach. International Scientific Journal “Theoretical \& Applied Science”, 12 (8), 98-100. http://dx.doi.org/10.15863/tas.2013.12.8.22

Antonova, M.Yu. (2012). Strukturna orhanizatsiia perelichennia v ekonomichnomu dyskursi. [Structural organisation of enumeration in economic discourse]. Visnyk Cherkaskoho universytetu. Seriia: Filolohichni nauky, 27 (240), 77-80.

China's botched stockmarket rescue. (2015). The Economist. Retrieved July 30, 2015, from http://www.economist.com/blogs/economist-explains/2015/07/economist-explains-22

Davis, R., Shrobe, H., \& Szolovits, P. (1993). What is a Knowledge Representation? AI Magazine. 14 (1), 17.

Dubois, S. \& Sankoff, D. (1997). Discourse Enumerators and Schegloff's Denominator. In G.R. Guy, C. Feagin, D. Schiffrin \& J. Baugh (Eds.), Towards a Social Science of Language. Papers in Honour of William Labov. Social Interaction and Discourse Structures (Vol. 2). The Netherlands, Amsterdam \& USA, Philadelphia: John Benjamins Publishing Company. http://dx.doi.org/10.1075/cilt.128.12dub

Falling bank shares. (2016). The Economist. Retrieved February 13, 2016, from http://www.economist.com/news/business-andfinance/21692863-european-banks-are-eye-new-financial-storm-tempest-fear

Galperin I.R. (1974). Stilistika anglijskogo jazyka. [Stylistics]. Moscow, Russia: Vysshaja shkola.

Geeraerts, D. \& Cuyckens, H.(2007). Introducing Cognitive Linguistics. In D. Geeraerts \& H. Cuyckens (Eds.), The Oxford Handbook of Cognitive Linguistics. (pp. 916-941). New York, USA: Oxford University Press. http://dx.doi.org/10.1093/oxfordhb/9780199738632.013.0001

Gryshchenko, Ya.S. (2013). Osobennosti diskursivnosti anglijskoj ody XVII-XIX vekov. [Discursiveness features of the English ode of the XVIIth-XIXth centuries]. Filologicheskie nauki. Voprosy teorii i praktiki, 3 (21), Part 1, 43-46.

Hart, C. (2015). Viewpoint in linguistic discourse: Space and evaluation in news reports of political protests. Critical Discourse Studies, 12 (3), p. 238-260. http://dx.doi.org/10.1080/17405904.2015.1013479

Krieken, K.\& Sanders, J. (2016). Diachronic changes in forms and functions of reported discourse in news narratives. Journal of Pragmatics, 91, 45-59. http://dx.doi.org/10.1016/j.pragma.2015.11.002

Levashova, V.A.(1977). Lingvisticheskaja priroda i funkcionirovanie stilisticheskogo prijoma perechislenija (na materiale anglijskogo jazyka). [Linguistic nature and functioning of the stylistic device of enumeration (on the material of the English language)]. Extended abstract of candidate's thesis, Moscow, Russia.

Levinskaja, R.I. (1988). Jekspressivnoe perechislenie v romanah L. Fejhtvangera. [Expressive enumeration in the Feuchtwanger's novels]. Stilistika issledovanija hudozhestvennogo teksta, 151-159.

Naumenko, L. (2015a). The subordinate concept "marketing" in the contemporary business English discourse. Scientific Journal "ScienceRise”, 5/1 (10), 87-91. http://dx.doi.org/10.15587/2313-8416.2015.42844

Naumenko, L.P. (2015b). Professional'nyj koncept "company" v sovremennom anglojazychnom biznes-diskurse. [The professional concept "company" in the contemporary business English discourse]. Vestnik Voronezhskogo gosudarstvennogo universiteta. Serija: Lingvistika i mezhkul'turnaja kommunikacija, 1, 69-75.

O’Brien, E. (2016). Commodity Shares Rally with Oil, Iron Ore; Aussie, Copper Fall. Bloomberg Business. Retrieved March 7, 2016, from http://www.bloomberg.com/news/articles/2016-03-06/aussie-slips-after-china-growthgoal-cut-asia-futures-tip-gains

Siantova, G. (2013). The Effect of Enumeration in the Language of Fictional Prose Helen Fielding: Bridget Jones: The Edge of Reason. International Journal of Arts and Commerce, 2 (7), 1-10.

Sanders, T. \& Spooren, W. (2007). Discourse and Text Structure. In D. Geeraerts \& H. Cuyckens (Eds.), The Oxford Handbook of Cognitive Linguistics. (pp. 916-941). New York, USA: Oxford University Press.

Sharov, S.V., Lubko, D.V. \& Osadchyi, V.V. (2015). Vybir modeli predstavlennia znan u systemi ISIKS. [Select model presentation of knowledge in ISICS]. Systemy obrobky informatsii, 11 (136), 108-111.

Vergez-Couret, M., Bras, M., Prevot, L., Vieu, L. \& Atallah, C. (2011). Discourse Contribution of Enumerative Structures involving "pour deux raisons". Constraints in Discourse. Retrieved from https://hal.archives-ouvertes.fr/file/index/docid/635319/ filename/Vergez-Couret et al. 2011_The discourse contribution of Enumerative Structures involving pour_deux raisons.pdf

Vetvinskaja, T.L. (1970). Perechislenie kak stilisticheskij prijom (na materiale anglijskogo jazyka) [Enumeration as a stylistic device (on the material of the English language)] (Unpuplished PhD dissertation). Taras Shevchenko State University of Kiev, Kiev, Ukraine. 